African Journal of Business and Economic Development | ISSN: 2782-7658

Vol. 1, Issue 5, Series 2 (May, 2021) | www.ijaar.org

Journal DOI: www.doi.org/10.46654/AJBED

Article DOI: www.doi.org/10.46654/AJBED.1533

\title{
THE IMPACT OF EXCHANGE RATE VOLATILITY ON ECONOMIC GROWTH IN NIGERIA: A DYNAMIC ECONOMETRIC APPROACH
}

\author{
AKINWOLERE BUKOLA COMFORT
}

Department of Economics, University of Abuja.

Email: akinwolerecomfort@ gmail.com, 08036282773

\begin{abstract}
This study examined the impact of exchange rate volatility on economic growth in Nigeria. The study covers the period of 1986 to 2019. Using time series data, the methodology adopted is the Vector Error Correction Mechanism to explore the impact of exchange rate volatility on the selected macroeconomic variables. The result indicated that exchange rate volatility has a significant impact on economic growth, specifically it has a positive impact on inflation, unemployment and balance of trade. On the other hand it has a negative impact on economic growth and investment. The recommendations made include; that relevant authorities should try to avoid systematic currency devaluations in order to maintain exchange rate volatility at a rate that allows adjustment of the balance of payments.
\end{abstract}

Keywords: Exchange rate, volatility, GDP, appreciation, depreciation. 


\section{Introduction}

The choice of exchange rate regime can affect economic growth through its effects on macroeconomic variables which are important determinants of growth. Factors such as export, international trade, capital flows are highly affected by the variation of exchange rate. Since the seventies, there has been an increasing importance attached to exchange rate in many countries which could be attributed to factors such as the floating exchange rate variability and volatility as well as the need for foreign exchange risk exposure management; the globalization process and the resultant increased rate and volume of funds flows among nations; the trade liberalization undertaken by developing countries since 1980s, resulting in opening up their economies; the internationalization of modern business; the continuing growth in world trade relative to national economies; the trends towards economic integration in some regions; and the rapid pace of change in the technology of money transfer (Gadanecz and Mehrotra, 2013).

Over the years, Nigeria has undergone different exchange rate policies, either depreciation or appreciation depending on the policy thrust of the government of the day. Aliyu (2011) noted that appreciation of exchange rate results in increased imports and reduced exports, while depreciation expands exports and discourages imports. Also, depreciation of exchange rate tends to cause a shift from foreign goods to domestic goods. Thus, it leads to diversion of income from importing countries to countries exporting through a shift in terms of trade, and this tends to have impact on the exporting and importing countries' economic balance of trade and growth. Although, a number of exchange rate reforms have been carried out by successive governments, the extent to which these policies have been effective in promoting exports has remained unascertained. This is because despite government efforts, the performance of the Nigerian economy remains very slow.

Various factors have been responsible for exchange rate fluctuation in Nigeria over time. However, changes in Oil Price have been the major driver of exchange rate fluctuation (Ogunjuyigbe \& Laisu, 2010). Since the discovery of Oil, Nigeria's reliance on income from Oil and Gas has further been buoyed by an almost consistent upward movement in the prices of crude oil reaching about $\$ 147$ per barrel in 2008 , before averaging $\$ 90$ per barrel in 2010 , $\$ 85$ per barrel in 2012, $\$ 79$ per barrel in 2014 and decreased to as low as $\$ 60$ per barrel in 2016, \$52 per barrel in 2017 and \$58 per barrel in 2018 (OPEC bulletin, 2018). Exchange rate fluctuated with changes in Oil Price as it stood at 118.5669 Naira to \$1 in 2008 and increased to 150.298 Naira to $\$ 1$ in 2010 with a decline in Oil Price. With further decline in Oil Price, exchange rate increased to 194.0294 Naira to $\$ 1$ in 2014 and $371.8655,375.1277$ and 373.08 Naira to \$1 in 2016, 2017 and 2018 respectively (OPEC bulletin, 2018).

Analysis of Nigeria's exchange rate movement from 1986 - 2019 showed that there exists a causal relationship between the exchange rate movements and economic growth (CBN, 2019). Consequently, the persistent depreciation of the exchange rate trended with GDP. In this context, the exchange rate movement in the 1990's trended with economic growth. Exchange rate volatility is accompanied by fluctuation in growth rate. For instance, while the exchange rate moved from 8.3 Naira to $\$ 1$ in 1990 to 22.05 Naira to $\$ 1$ and 21.86 Naira to $\$ 1$ in 1993 and 1995 respectively, economic growth decreased from 11.36 percent in 1990 to 1.56 percent in 1993 and 2.15 percent in 1995. Also, when the exchange rate moved from 21.86 in 1995 to 92.69 and 102.11 in 1999 and 2000 respectively and rose thereafter to 133.5 
in 2004 and averaged 198.74 between 2005-2019, economic growth trended in the same direction (CBN, 2019).

Thus, from the above scenario, it is important to note that there is a strong nexus between exchange rate and Gross Domestic Product (GDP). It is therefore not surprising that, exchange rate is among the most watched, analyzed and government manipulated macroeconomic indicators. Most countries attempt to moderate their domestic currency fluctuations by imposing restrictions on exchange rate movements (Benita \& Lauterbach, 2007). It is a key macroeconomic measure in the context of general economic reform programmes and because of its importance, government takes active part in its determination. Specifically, it is important as the connection between the pricing systems of countries, as a price in the allocation of real resources among tradable and non-tradable sectors, as a promoter or otherwise of imports and exports, and as an instrument in the design of the balance of trade programme of a country. Various macroeconomic policies notably, fiscal and monetary had from time to time been adopted to address this problem of exchange rate fluctuation. Unfortunately, these measures have met with little or no success and this has hindered the achievement of other macroeconomic objectives. It is in this light that this study is devoted to carrying out an analysis of the impact of exchange rate volatility on economic growth in Nigeria, since the Structural Adjustment Programme (SAP) of 1986 to 2019 and its policy implication.

The objective of this study is to analyse the impact of exchange rate volatility on economic growth in Nigeria for a period of 34 years (1986 - 2019). The choice of 1986 as a base year was to enable us see the changes that would have occurred as a result of the Structural Adjustment Programme (SAP) that was meant to holistically reform the Nigerian economy then and to track the impact of the democratic government of Nigeria since its return in 1999.

\section{Literature Review and Theoretical Framework}

\subsection{Conceptual Review}

\section{a Exchange Rate}

Exchange rate is the price of the currency of one country expressed in terms of the currency of another. For example, the Nigerian Naira has exchange rate against the U.S. dollar and many other currencies. It may be expressed as nominal exchange rate or real exchange rate. According to Akintola and Lawal (2012), the nominal exchange rate is a monetary concept which measures the relative price of two currencies e.g. Naira in relation to dollar $(\mathrm{N} / \$)$, while the real exchange rate is a real concept that measures the relative price or value of different countries' products.

Nominal exchange rate is used in this study as the rate of the Naira to dollar that is the amount of naira exchange to a dollar. This measurement is in-line with various studies carried on exchange rate such as Yaqub (2010); Iyeli and Utting (2017). Rasaq (2012); Attah-Obeng, Enu, Osei-Gyimah and Opoku (2014). 


\section{b. Volatility}

Volatility measures the rate and magnitude of price changes around a trend. In other words, it captures the deviation of the actual observed price from its normal or expected value (Pindyck, 2002). The computation and estimation of price volatility is not unique to exchange rate and is heavily discussed in a wide range of economic fields. Earlier studies on volatility focused on asset or security returns.

In principle, measures of exchange rate volatility can be classified into two broad categories (Matthews, 2010). First, realized historical volatility that measures the volatility of observed past prices. Secondly, stochastic volatility which captures volatility at a given point in time also considering past realization of volatility. From the foregoing, volatility in this context could rightly be defined as the rate at which the price of exchange rate increases or decreases for a given period (Kashif et.al 2010). It is measured by calculating the standard deviation of the annualized returns over a given period of time. In financial market, volatility measurement is based on the standard deviation of the asset return, a variable that appears in option pricing formulas, where it denotes the volatility of the underlying asset return from now to the expiration of the option (Shiller and Radikoko, 2014).

Volatility is measured in this study using the econometrics approach of calculating volatility clustering. This approach used the Generalized Auto-Regressive Conditional Heteroscedasticity $(\mathrm{GARCH})$ model. This measurement is consistent with other studies on exchange rate volatility such as Tarawalie et al. (2012)

\section{c Economic Growth}

Economic growth is an increase in the production of goods and services over a specific period. To be most accurate, the measurement must remove the effects of inflation.Economic growth creates more profit for businesses. As a result, stock prices rise which gives companies capital to invest and hire more employees. As more jobs are created, incomes rise. Consumers have more money to buy additional products and services. Purchases drive higher economic growth. For this reason, all countries want positive economic growth. This makes economic growth the most-watched economic indicator (Silas \&Matas, 2018).

Thus, the study measures economic growth in terms of Gross Domestic Product as it is the best way to measure economic growth. This is because, it takes into account the country's entire economic output. It includes all goods and services that businesses in the country produce for sale. It doesn't matter whether they are sold domestically or overseas. GDP measures final production. It doesn't include the parts that are manufactured to make a product. It includes exports because they are produced in the country. Imports are subtracted from economic growth. Most countries including Nigeria measure economic growth quarterly.

\subsection{Empirical Review}

There are various empirical literatures that have been carried out in developing and developed economies on the linkage between exchange rate and economic growth. Different statistical information and econometrics techniques were used in these empirical studies. The relationship between exchange rate volatility and economic growth has received considerable 
attention in previous studies. Despite the immense research on the topic, there is still no general unanimity that has been reached on the relationship between exchange rate volatility and economic growth(BarGuellil et al., 2018). The literature reveals diversified outcomes are making this topic an empirical question which still requires further investigation. While some studies revealed the existence of a negative relationship, others established a positive nexus, while others found no significant relationship at all (Iyeli and Utting, 2017). Some of the previous researches carried out on the topic are reviewed as follows:

For studies conducted on other developing countries, Attah-Obeng, Enu, Osei-Gyimah and Opoku (2013) examined the relationship between GDP growth rate and exchange rate in Ghana from the period 1980 to 2012. The study employed the graphing of the scatter diagram for the two variables which are GDP growth rate and exchange rate, established the correlation between GDP growth rate and exchange rate using the Pearson's Product Moment Correlation Coefficient (PPMC) and finally estimated the simple linear regression using Ordinary Least Square (OLS). This result conformed with the theory that undervaluation (high exchange rate) stimulates economic growth in the short run. Thus, policy makers should stabilise monetary and fiscal policies in the long run.

Similarly, Ganesh, Moses and Musyoki (2012) examined the impact of real exchange rate volatility on economic growth in Kenya. The study employed the Generalized Autoregressive Condition of Heteroscedasticity $(\mathrm{GARCH})$ and computation of the unconditional standard deviation of the changes to measure volatility and Generalized Method Moments (GMM) to assess the impact of the real exchange rate volatility on economic growth for the period, January 1993 to December 2009. Data for the study were collected from Kenya National Bureau of Statistics, Central Bank of Kenya and International Monetary Fund Database by taking monthly frequency. The study found that RER was very volatile for the entire study period. Kenya's RER generally exhibited appreciating and volatility trend, implying that in general, the country's international competitiveness deteriorated over the study period. The RER Volatility reflected a negative impact on economic growth of Kenya.

Examining the effect of exchange rate shocks on economic growth in Turkey for the period 1987:1 to 2008:3, Berument et al. (2012) used sign restriction approach to divide exchange rate shocks into monetary policy fluctuations and portfolio preference fluctuations. The study estimated models where real GDP is dependent on nominal GDP, GDP deflators, exchange rate, interest rate and money supply, using the Vector Autoregressive (VAR) technique. The study found no clear relationship between exchange rate shocks and economic growth but concluded that economic growth depended on the sources of exchange rate shocks.

Using time-series data spanning from 1971 to 2009, Mori, Asid, Lily, Mulok and Loganathan (2012) investigated the effects of exchange rates on economic growth in Malaysia. The results of ARDL bounds test suggest that long-run cointegration exists between both nominal and real exchange rates and economic growth with a significant positive coefficient recorded for real exchange rate. The study concluded that both exchange rates have a similar causal effect towards economic growth and suggested that a systematic exchange rate via monetary policy should be properly developed to promote the stability and sustainability of economic growth in Malaysia. 
For panel cross country studies, Umaru et al. (2019) examined the effects of exchange rate volatility on economic growth of West African English-speaking countries. Macroeconomic data used for this study were obtained from the World Bank Data Stream between 1980 to 2017 and analyzed using Stata 14 panel data regression analysis. The results obtained showed that the independent variable (real exchange rate) is statistically significant and negatively related to the dependent variable (GDP) in West African English-speaking countries excluding time-invariant variables.

BarGuellil et al. (2018) examined the impact of exchange rate volatility on economic growth. An empirical investigation based on a sample of 45 developing and emerging countries over the period of 1985 to 2015 was conducted using the difference and system generalized method of moments estimators. Findings suggested that the generalized autoregressive conditional heteroskedasticity-based measure of nominal and real exchange rate volatility has a negative impact on economic growth. Also, the effect of exchange rate volatility depends on the exchange rate regimes and financial openness, that is, volatility is more harmful when countries adopt flexible exchange rate regimes and financial openness.

In a similar research, Tarawalie et al. (2012) investigated the effects of exchange rate volatility on output growth and inflation in the West African Monetary Zone (consisting of Ghana, The Gambia, Guinea, Liberia, Nigeria and Sierra Leone) following exchange rate regime shift. Results from the study revealed that, while exchange rate volatility is inflationary across all the countries, its effects on output growth differ. Specifically, volatility and depreciation in particular negatively affect real GDP growth in Liberia and Sierra Leone but positively impacts on output in the other countries albeit weakly. The difference in direction and magnitude of effect is not far-fetched from the differences in macroeconomic conditions prevailing in each country.

Examining the impact of real exchange rate volatility on long-run economic growth for advanced and emerging economies over the period 1970 to 2009, Holland et al. (2011) observed that, high (low) exchange rate volatility positively (negatively) affects real GDP growth rate. The study noted that controlling for exchange rate volatility in a model containing levels of exchange rate and exchange rate misalignment renders the variables insignificant, thereby suggesting that exchange rate stability is more crucial in propelling long-run growth than exchange rate misalignment. The study, however, did not find any significant link between exchange rate volatility and long-run productivity growth.

Similarly, Gadanecz and Mehrotra (2013) revealed non-linearities between real exchange rate volatility and output volatility among emerging market economies. Their finding suggests that real exchange rate volatility aids in absorbing shocks as well as limit output volatility, but too much of volatility in exchange rate increases output volatility.

Also, study carried out by Polodoo, Seetanah and Padachi (2011) on the "impact of exchange rate volatility on economic growth on small island developing states" using the generalised method of moments found out that in dynamic setting, volatile exchange rates do not influence economic growth.Another study by Holland, Vieira, Silva and Bottecchia (2011) examined exchange rate volatility on economic growth in 82 advanced and emerging economies using panel econometrics analysis discovered that a relatively less volatile real exchange rate structure has a positive effect on economic growth and vice-versa. 
For studies conducted in Nigeria, Ubah (2015) examined the effect of exchange rate volatility on economic growth in Nigeria on the basis of annual data from 1980 to 2012. Employing the Generalised Autoregressive Conditional Heteroscedasticity (GARCH) technique to generate exchange rate volatility, the relationship between exchange rate volatility and economic growth was estimated. Findings further showed that in the short run, economic growth is negatively responsive to exchange rate volatility in Nigerian case, while in the long run, a negative relationship exists between the two variables. The study recommended control of import content of both public and private expenditure, greater diversification of the economy through investment in key productive sectors of the economy to guard against the vicissitude exchange rate volatility.

In a related study, Iyeli and Utting (2017) assessed the effect of exchange rate volatility on Economic Growth in Nigeria from 1970 to 2011. The model formulated depicts Real GDP as the dependent variable, while Exchange Rate (EXR), Balance of Payment (BOP) Oil Revenue (OREV) and inflation (INF) are independent variables. The study employed the Johansen Co-integration estimation techniques to test for the short and long runs effect of the variables used. The ADF test revealed that all the variables are stationary. From the parsimonious model, the results show that OREV and EXR are positively related to GDP. Further findings revealed that there exist two equations at 5\% level in both trace and MaxEigen statistic. This implies that exchange rate volatility and oil revenue contribute positively to GDP in the long run.

In addition to the aforementioned reviews, Ismaila (2016), examined exchange rate depreciation and Nigerian economic performance after structural adjustment programmes (SAP). The study used cointegration and error correction mechanism. The variables used were broad money supply, net export and total government expenditure, real output and exchange rate. The results show that broad money supply, net export and total government expenditure have significant impact on real output performance in the long run, while exchange rate has direct and insignificant effect on the Nigerian economic growth in both short and long run. Therefore, the study suggested that policy makers should not totally rely on exchange rate depreciation policy instrument to induce economic growth.

Using GARCH Models, Dahiru and Asemota (2013) examined exchange rate volatility with monthly exchange rate return series from 1985 to 2011 for Naira/US dollar return and from 2004 to 2011 for Naira/British Pounds and Naira/Euro returns. The study compared estimates of variants of GARCH models with break in respect of the US dollar rates with exogenously determined break points. The results revealed presence of volatility in the three currencies and equally indicate that most of the asymmetric models rejected the existence of a leverage effect except for models with volatility break. Evaluating the models through standard information criteria, volatility persistence and the log likelihood statistic, showed that results improved with estimation of volatility models with breaks as against those of GARCH models without volatility breaks and that the introduction of volatility breaks reduces the level of persistence in most of the models.

Azeez, Kolapo and Ajayi (2012) also examined the effect of exchange rate volatility on macroeconomic performance in Nigeria from 1986 to 2010. The model formulated depicts Real GDP as the dependent variable, while Exchange Rate (EXR), Balance of Payment (BOP) and Oil Revenue (OREV) are proxied as independent variables. It employed the 
Ordinary Least Squared (OLS) and Johansen co-integration estimation techniques to test for the short and long runs effects respectively. The results showed that oil revenue and balance of payment exert negative effects, while exchange rate volatility contributes positively to GDP in the long run. The study recommended that monetary authorities should pursue policies that would curb inflation and ensure stability of exchange rate.

In the same vein, Danmola (2013) analysed the impact of exchange rate volatility on macroeconomic variables in Nigeria. The Ordinary least square and Granger Causality was used to test the relationship between them. The variables used were exchange rate, GDP and investment. It was observed that exchange rate has a significant impact on economic growth. The study then recommended exchange rate control.

In a related study, Adeniran, Yusuf and Adeyemi (2014) examined the impact of exchange rate on Nigerian economic growth from 1986 to 2013. Employing the correlation and regression analysis, the ordinary least square (OLS) method was used to analyze the data. The result revealed that exchange rate has positive and insignificant impact on Nigerian economic growth and recommended that government should encourage the export promotion strategies in order to maintain a surplus balance of trade and also conducive environment, adequate security, effective fiscal and monetary policies, as well as infrastructural facilities should be provided so that foreign investors will be attracted to invest in Nigeria.

Using Vector Error Correction Model (VECM), Akinlo and Lawal (2012) examined the impact of exchange rate on industrial production in Nigeria over the period 1986-2010. The findings confirmed the existence of long run relationship between industrial production index and exchange rate, money supply and inflation rate. Moreover, exchange rate volatility had no perceptible impact on industrial production in the short run but had positive impact in the long run.

Based on the annual time series data for the period 1970 to 2009 and employing vectorautoregressive model, Dada and Oyeranti (2012) analysed the impact of exchange rate on macroeconomic aggregates in Nigeria. The estimation results showed that there was no evidence of a strong direct relationship between changes in the exchange rate and GDP growth. Rather, Nigeria's economic growth has been directly affected by fiscal and monetary policies and other economic variables particularly the growth of exports (oil) and concluded that improvements in exchange rate management were necessary but not adequate to revive the Nigerian economy.

On the effect of exchange rate on the economic sector output, Ehinomen and Oladipo (2012) examined the impact of exchange rate management on the growth of the manufacturing sector in Nigeria. Ordinary Least Square (OLS) multiple regression analysis was employed to analysed time series data which spanned between 1986 to 2010. The empirical result of this study showed that depreciation which forms part of the structural adjustment programme (SAP), 1986, and which dominated the period under review has no significant relationship with the manufacturing sector's productivity. It was observed that in Nigeria, exchange rate appreciation has a significant relationship with domestic output and recommended that government should direct its exchange rate management policy towards exchange rate appreciation in order to reduce the cost of production in the manufacturing sector which 
depends heavily on foreign inputs, while there should be total ban of importation on consumer and intermediate goods that can be produced locally.

\subsection{Theoretical Framework}

Fisher (1938), in his Quantity Theory of Money postulated that exchange rates are determined in the process of equilibrating or balancing the stock or total demand and supply of money in each economy. According to the monetary approach, the nominal demand for money is stable in the long run and positively related to the level of nominal national income but inversely related to interest rate. The nation's money supply is equal to its monetary base times the multiplier. The nation's monetary base is equal to the domestic credit created by its monetary authorities plus its international reserve. Unless satisfied domestically, an excess supply of money in the nation results in an outflow of reserves, or a balance of payment deficit under fixed exchange rates and a depreciation of the nation's currency (without any international flow of reserves) under flexible exchange rate. The opposite takes place with an excess demand for money in the nation.

In this theory, attention is given to the stock of currencies in comparison to the willingness of people to hold these stocks. According to the monetary theory, exchange rates adjust to ensure that the quantity of money in each currency supplied is equal to the quantity demanded (Rasaq, 2012). Both Quantity Theory of Money (QTM) and Purchasing Power Parity (PPP) have been used in support of the aforementioned theory.

Thus, Fisher's Quantity Theory of Money (QTM) states that there is a direct relationship between the quantity of money and the level of prices of goods and services sold (Virendra, 2011). In other words, more money equals more inflation. In a domestic framework, the equation below is formulated to explain the relationship between money supply and inflation:

$$
\mathrm{MV}=\mathrm{PY}
$$

$M=$ Money supply/demand $; V=$ Velocity of circulation (the number of times money change hands); $P=$ Average price levels; $Y=$ Output $(G D P)$

Finally, it can be concluded that an increase in the money supply leads to inflation, which in turn results to a decrease in the value of money or purchasing power. Similarly, if this is considered in an international context, the following implications will apply:

Firstly, a rapid increase in money supply (in the home currency), which as stated earlier means inflation, will put into effect the PPP resulting in the depreciation of the currency's exchange rate. Secondly, a higher interest rate will also result in the currency's depreciation because of the positive relationship between interest rates and money in circulation.

Finally, if the domestic GDP grows faster than overseas GDP, the demand for money will increase. Assuming there is a given supply of money, the exchange rate will decrease. 


\section{METHODOLOGY}

\subsection{Research Design}

The research employed the analytical research design using the Vector Error correction model (VECM) to establish a long run and short run interaction between exchange rate volatility and economic growth in Nigeria. VECM belongs to a category of multiple time series model commonly used for data where the underlying variables have a long-run stochastic trend, also known as co integration. It is a theoretically driven approach useful for estimating both short-term and long-term effect of one time series on another. Before specifying the time series regression there was a need to test and extract the latent exchange rate volatility process. This was done with the use of the Generalized Auto-Regressive Conditional Heteroskedasticity (GARCH).

The stationarity test (unit root test) was carried out first using the Augmented Dickey Fuller (ADF) test on each variable to test for stationarity and avoid for spurious regression as suggested by Phillips and Moon (1999). Depending on the stationarity test result, the cointegration test was conducted to determine if the variables have a long-run equilibrium relationship. The Johansen's cointegration test was used to test for long run relationship between variables.

\subsection{Model Specification}

\section{a Measuring Exchange Rate Volatility}

The ARCH model of Engle (1982) provides a systematic framework for modeling volatility process. The basic premise is that the mean exchange rate volatility is serially uncorrelated, but is dependent. This dependence is usually modelled as a simple quadratic function of its lagged values (Tsay, 2002).

Specifically, the ARCH process imposes an autoregressive structure on the conditional variance that permits volatility shocks to persist over time. It can therefore allow for volatility clustering. The general form of the model, denoted by $\operatorname{ARCH}(q)$ begins with the Autoregressive Model;

$$
Y_{t}=\alpha_{0}+\alpha_{1} Y_{t-1}+\alpha_{1} Y_{t-1}+\alpha_{1} Y_{t-1}+\cdots+\alpha_{P} Y_{t-P}+\epsilon_{t}=\alpha_{0}+\sum_{i=1}^{p} \quad \alpha_{i} Y_{t-i}+\epsilon_{t}
$$

Where $\mathrm{Y}_{\mathrm{t}}$ is the dependent variable, $\alpha_{i}$ are parameters to estimate and $\epsilon_{t}$ the error term. The lags of the dependent variables can be stack together as $\mathrm{X}_{\mathrm{t}}$ and the $\alpha_{i}{ }^{\prime} s$ as $\varphi$ which is rewritten as;

$Y_{t}=X_{t} \varphi+\epsilon_{t}$

Where the error term is assumed to be normally distributed with 0 mean and variance $h_{t}$ also written as; 
$\epsilon_{t} \sim N\left(O, h_{t}\right)$

The ARCH(q) model estimated with Maximum Likelihood Procedures is given as;

$h_{t}=\alpha_{0}+\sum_{i=1}^{q} \quad \alpha_{i} \epsilon_{t-1}^{2}+V_{t}$

$V_{t} \sim \operatorname{IIN}\left(0, h_{t}\right)$

The main problem with an ARCH model is that it requires a large number of lags to catch the nature of the volatility, this can be problematic as it is difficult to decide how many lags to include besides, it produces a non-parsimonious model where the non-negativity constraint could fail. The GARCH model is usually much more parsimonious and often a $\operatorname{GARCH}(1,1)$ model is sufficient, this is because the GARCH model incorporates much of the information that a much larger ARCH model with large numbers of lags would contain.

Due to these deficiencies of ARCH, Bollerslev (1986) generalised the ARCH process by allowing the conditional variance to be a linear function of $p$ lagged conditional variances in addition to $q$ past squared errors. In other words, $\operatorname{GARCH}(p, q)$ implies the following form of the conditional variance:

$$
h_{t}=\alpha_{0}+\sum_{i=1}^{q} \quad \alpha_{i} \epsilon_{t-1}^{2}+\sum_{j=1}^{p} \quad \beta_{i} h_{t-j}+V_{t}
$$

Where $\alpha_{0}$ is the constant term, $\epsilon_{t-1}^{2}$ is the ARCH process, $h_{t-j}$ is the GARCH term.

To ensure the conditional variance is positive, an inequality restriction must be imposed on the variance equation in (3.6):

$\alpha_{0}>0$ and $\alpha_{i} \geq 0, \beta_{i} \geq 0, \forall i, \mathrm{j}$

According to Blanchard and Gali (2007) and Plante and Thrum (2012) amongst others, real oil prices follow an Autoregressive $A R(p)$ process with time varying volatility, where volatility follows a mean reverting Moving Average MA(1) process. Specifically;

$$
\begin{aligned}
& E X R_{t}=\rho_{1} E X R_{t-1}+\rho_{2} E X R_{t-2}+\rho_{3} E X R_{t-3}+\cdots+\rho_{p} \log +e^{\sigma t} V_{t} \\
& =\sum_{i=1}^{p} \quad \rho_{i} \log E X R_{t}+e^{\sigma t} V_{t}
\end{aligned}
$$

$$
\sigma_{t}^{2}=\left(1-\delta_{\sigma}\right) \underline{\sigma}+\delta_{1} \sigma_{t-1}^{2}+\gamma_{1} V_{t-1}^{2}+V_{\sigma, t}
$$

Note:

$\left\{\mathrm{V}_{\mathrm{t}}, \mathrm{V}_{\sigma, \mathrm{t}}\right\} \sim \mathrm{N}(0,1)$ i.e. zero mean and constant variance 
Where;

EXR $_{\mathrm{t}}$ is Exchange Rate, $\sigma^{2}$ is Variance, $\rho, \gamma$ and $\delta$ are parameters to be estimated $\sigma$ is the unconditional mean of $\sigma_{t}^{2}$. The shock to Exchange Rate volatility $\mathrm{V}_{\sigma, \mathrm{t}}$ is assumed to be independent of the error term $V_{t}$. The postulated oil price process is the same as in Fernandez-Villaverde et al. (2015) with time varying volatility. A method to test for the significance of GARCH errors using the Lagrange multiplier test was proposed by Engle (1982).

The null hypothesis is that, in the absence of ARCH/GARCH components, we have

$\mathrm{H}_{0}: \delta_{1}=0 \quad ; \gamma_{1}=0$

The alternative hypothesis is

$\mathrm{H}_{1}: \delta_{1} \neq 0 \quad ; \gamma_{1} \neq 0$

That is, in the presence of $\mathrm{ARCH}$ components, the estimated coefficients $\delta_{1}$ must be significant. In a sample of $T$ residuals under the null hypothesis of no GARCH errors, the test statistic $T R^{2}$ follows $\chi^{2}$ distribution with $q$ degrees of freedom. If $T R^{2}$ is greater than the Chisquare table value, we reject the null hypothesis and conclude there is a GARCH effect. If $T R^{2}$ is smaller than the Chi-square table value, we do not reject the null hypothesis. Also, we can also test the null hypothesis using the probability value of the Langrangian Multiplier (LM) statistics. We accept the null hypothesis if the probability falls outside the conventional levels of significance. That is, if $p>0.05$, it accepts the null hypothesis that there is no GARCH effect. Where the reverse is the case, it will reject the null hypothesis.

\section{b. Multivariate Time Series Model}

In an attempt to justify the impact of foreign exchange on macroeconomic performance in the Nigerian economy, important macroeconomic variables such as gross domestic product, exchange rate, balance of trade, investment, inflation and unemployment will be considered in building the model for this study. Also, a VECM model shall be used to carry out the analysis. The model used is adapted from the work of Iyeli and Utting (2017) who examined exchange rate volatility and economic growth in Nigeria. Their model was given as

$\mathrm{RGDP}=\mathrm{f}(\mathrm{EXR}, \mathrm{OREV}, \mathrm{INF})$

Where RGDP= real gross domestic product, $\mathrm{EXR}=$ exchange rate, OREV is Oil Revenue and $\mathrm{INF}=$ inflation rate. OREV was dropped as it was not part of the macroeconomic indicators under consideration in this study. However, in line with the objectives of the study, other important macroeconomic indicators such as unemployment and money supply were included.

VECM model comes to play when it has been established that, there exists a long-run relationship between the variables under consideration. The VECM regression equation is stated below as: 


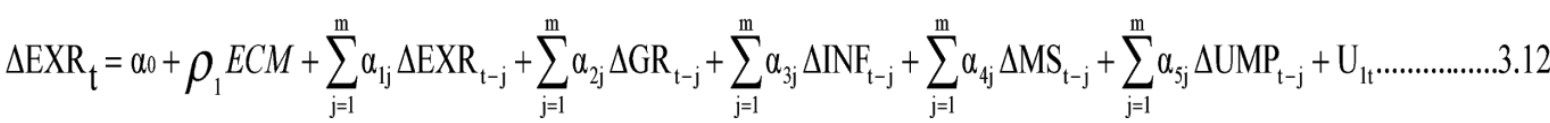

$$
\begin{aligned}
& \Delta \mathrm{GR}_{\mathrm{t}}=\beta_{0}+\rho_{2} E C M+\sum_{\mathrm{j}=1}^{\mathrm{m}} \beta_{\mathrm{lj}} \Delta \mathrm{EXR}_{\mathrm{t}-\mathrm{j}}+\sum_{\mathrm{j}=1}^{\mathrm{m}} \beta_{2 \mathrm{j}} \Delta \mathrm{GR}_{\mathrm{t}-\mathrm{j}}+\sum_{\mathrm{j}=1}^{\mathrm{m}} \beta_{3 \mathrm{j}} \Delta \mathrm{INF}_{\mathrm{t}-\mathrm{j}}+\sum_{\mathrm{j}=1}^{\mathrm{m}} \beta_{4 \mathrm{j}} \Delta \mathrm{MS}_{\mathrm{t}-\mathrm{j}}+\sum_{\mathrm{j}=1}^{\mathrm{m}} \beta_{5 \mathrm{j}} \Delta \mathrm{UMP}_{\mathrm{t}-\mathrm{j}}+\mathrm{U}_{\mathrm{lt}} \ldots \ldots \ldots \ldots \ldots \ldots \ldots . .3 .13 \\
& \Delta \mathrm{INF}_{\mathrm{t}}=\lambda_{0}+\rho_{3} E C M+\sum_{\mathrm{j}=1}^{\mathrm{m}} \lambda_{\mathrm{j} j} \Delta \mathrm{EXR}_{\mathrm{t}-\mathrm{j}}+\sum_{\mathrm{j}=1}^{\mathrm{m}} \lambda_{2 \mathrm{j}} \Delta \mathrm{GR}_{\mathrm{t}-\mathrm{j}}+\sum_{\mathrm{j}=1}^{\mathrm{m}} \lambda_{3 j} \Delta \mathrm{INF}_{\mathrm{t}-\mathrm{j}}+\sum_{\mathrm{j}=1}^{\mathrm{m}} \lambda_{4 j} \mathrm{\Delta MS_{ \textrm {t } - \mathrm { j } }}+\sum_{\mathrm{j}=1}^{\mathrm{m}} \lambda_{\mathrm{sj}} \Delta \mathrm{UMP}_{\mathrm{t}-\mathrm{j}}+\mathrm{U}_{1 \mathrm{t}} \ldots \ldots \ldots \ldots \ldots \ldots \ldots . . .14 \\
& \Delta \mathrm{MS}_{\mathrm{t}}=\gamma_{0}+\rho_{4} E C M+\sum_{\mathrm{j}=1}^{\mathrm{m}} \gamma_{\mathrm{lj}} \Delta \mathrm{EXR}_{\mathrm{t}-\mathrm{j}}+\sum_{\mathrm{j}=1}^{\mathrm{m}} \gamma_{2 \mathrm{j}} \Delta \mathrm{GR}_{\mathrm{t}-\mathrm{j}}+\sum_{\mathrm{j}=1}^{\mathrm{m}} \gamma_{\mathrm{j} j} \Delta \mathrm{INF}_{\mathrm{t}-\mathrm{j}}+\sum_{\mathrm{j}=1}^{\mathrm{m}} \gamma_{4 \mathrm{j}} \Delta \mathrm{MS}_{\mathrm{t}-\mathrm{j}}+\sum_{\mathrm{j}=1}^{\mathrm{m}} \gamma_{\mathrm{sj}} \mathrm{\Delta LUMP_{ \textrm {t } - \mathrm { j } }}+\mathrm{U}_{1 \mathrm{t}} \ldots \ldots \ldots \ldots \ldots \ldots \ldots . .3 .15 \\
& \Delta \mathrm{UMP}_{\mathrm{t}}=\delta_{0}+\rho_{5} E C M+\sum_{\mathrm{j}=1}^{\mathrm{m}} \delta_{\mathrm{lj}} \Delta \mathrm{EXR}_{\mathrm{t}-\mathrm{j}}+\sum_{\mathrm{j}=1}^{\mathrm{m}} \delta_{2 \mathrm{j}} \Delta \mathrm{GR}_{\mathrm{t}-\mathrm{j}}+\sum_{\mathrm{j}=1}^{\mathrm{m}} \delta_{3 \mathrm{j}} \Delta \mathrm{NNF}_{\mathrm{t}-\mathrm{j}}+\sum_{\mathrm{j}=1}^{\mathrm{m}} \delta_{4 \mathrm{j}} \Delta \mathrm{MS}_{\mathrm{t}-\mathrm{j}}+\sum_{\mathrm{j}=1}^{\mathrm{m}} \delta_{5 \mathrm{j}} \Delta \mathrm{UMP}_{\mathrm{t}-\mathrm{j}}+\mathrm{U}_{1 \mathrm{t}} \ldots \ldots \ldots \ldots \ldots \ldots \ldots . . .16
\end{aligned}
$$

A negative and significant coefficient of the VECM (i.e. $\rho$ in the above equations) indicates that any short-term fluctuations between the independent variables and the dependent variable will give rise to a stable long run relationship between the variables.

Where, GR is growth rate; BoT is Balance of Trade; UMP is Unemployment Rate EXR is Exchange Rate; INV is Investment; INF is Inflation Rate

$\alpha_{0}-\alpha_{6}, \beta_{0}-\beta_{6}, \lambda_{0}-\lambda_{6}, \gamma_{0}-\gamma_{6}, \delta_{0}-\delta_{6}$, and $\phi_{0-} \phi_{6}$ are Coefficients to be estimated.

$\mathrm{U}_{1 \mathrm{t}}-\mathrm{U}_{6 \mathrm{t}}$ are the Gaussian white noise that are independently and identically distributed random variable.

\subsection{Sources of Data}

The data on GDP Growth rate and Inflation rate were from the National Accounts Statistics and the Consumer Price Index (CPI) of the National Bureau of Statistics (NBS) respectively. Also, from NBS are the data on Unemployment using the Labour force Survey Reports. The data for other variables (Investment, Exchange Rates and Balance of Trade) were sourced from the Central Bank of Nigeria (CBN) Statistical Bulletin, 2019. The data sample size covers 34 years $(1986$ - 2019). The Base year of 1986 was chosen to enable for analysis on the impact of exchange rate on macroeconomic performance during the structural adjustment economic reforms era. Also, the time period was chosen because a time series analysis requires a number of years for it to be meaningful and to take proper account of the persistent dynamics.

\section{RESULTS AND DISCUSSION}

\subsection{Data Analyses and Interpretation Of Results}

The data were analysed using Econometric views (E-views) and adopting various econometric techniques to determine the direction of interaction amongst the variables under consideration. Graphical analyses were carried out in order to observe trends' flows in the variables under consideration. Diagnostic tests were conducted on the data to be sure that 
they were valid enough for relevant inferences to be made. The model was then estimated, and interpretations of major findings were made.

\subsection{Descriptive Statistics}

The descriptive statistics is used to examine the statistical properties of the variables such as their measure of central tendencies like the mean and median as well as their measure of dispersion like the maximum, minimum and standard deviation. The descriptive statistics also indicate the pattern of distribution of the variables to identify if the variables were normally distributed or not.

\section{Table 4.1 Descriptive Statistics}

\begin{tabular}{|l|c|c|c|c|c|c|}
\hline & EXR & BoT & EGr & INF & MS & UMP \\
\hline Mean & 124.5784 & 4068.981 & 4.856765 & 19.96417 & 4220.703 & 18.80059 \\
\hline Median & 119.7685 & 1930.821 & 4.760000 & 12.00000 & 652.0400 & 18.29000 \\
\hline Maximum & 417.4642 & 19620.19 & 14.60000 & 76.75887 & 17093.93 & 29.80000 \\
\hline Minimum & 2.020575 & -19488.70 & -0.550000 & 0.223606 & 11.35000 & 10.50000 \\
\hline Std. Dev. & 124.7672 & 7973.721 & 3.666145 & 18.69839 & 5969.745 & 3.680975 \\
\hline Skewness & 1.190885 & 0.209092 & 0.620907 & 1.717681 & 1.041843 & 0.937559 \\
\hline Kurtosis & 3.479075 & 4.339967 & 2.822580 & 4.770020 & 2.340773 & 4.786990 \\
\hline & & & & & & \\
\hline Jarque-Bera & 2.361652 & 2.791386 & 2.229240 & 1.115748 & 3.766466 & 3.504988 \\
\hline Probability & 0.115286 & 0.247661 & 0.328040 & 0.210025 & 0.233938 & 0.118630 \\
\hline & & & & & & \\
\hline Sum & 4235.667 & 138345.4 & 165.1300 & 678.7818 & 143503.9 & 639.2200 \\
\hline Sum Sq. Dev. & 513706.1 & $2.10 \mathrm{E}+09$ & 443.5403 & 11537.78 & $1.18 \mathrm{E}+09$ & 447.1360 \\
\hline & & & & & & \\
\hline Observations & 34 & 34 & 34 & 34 & 34 & 34 \\
\hline
\end{tabular}

\section{Source: Author's computation using E-Views Software, Version 11 (2019)}

The descriptive statistics above indicate that all the variables have equal number of observations of 34 each. The results also indicate the statistical properties of the variables such as mean, median, maximum, minimum, etc. as well as the pattern of distribution of the variables.

On the distribution, it was observed from the above descriptive statistics with reference to the Jarque-Bera estimates and probability value, that all the variables are normally distributed as indicated by their probability values of the Jarque-Bera statistic given as $0.115286,0.247661$, $0.328040,0.210025,0.233938$ and 0.118630 respectively which are higher than 0.05 level of significance.

\subsection{Generalized Autoregressive conditionally heteroscedastic (GARCH) Result}

The data Analysis begins by testing as well as extracting exchange rate volatility using the Generalized Autoregressive conditionally heteroscedastic (GARCH) model. 
African Journal of Business and Economic Development | ISSN: 2782-7658

Vol. 1, Issue 5, Series 2 (May, 2021) | www.ijaar.org

Journal DOI: www.doi.org/10.46654/AJBED

Article DOI: www.doi.org/10.46654/AJBED.1533

Table 4.2 Estimating GARCH $(1,1)$

Mean Equation

Variable

Coefficient

Std. Error

z-Statistic

Prob.

\begin{tabular}{crrrr}
\hline GARCH & -0.089722 & 0.000530 & -169.4428 & 0.0000 \\
C & 128.7483 & 0.190417 & 676.1405 & 0.0000
\end{tabular}

Variance Equations

\begin{tabular}{crrrr}
\hline$\alpha(1)$ & 401.6583 & 42.45590 & 9.460601 & 0.0000 \\
$\alpha(2)$ & 1.618658 & 0.007131 & 226.9779 & 0.0000 \\
$\alpha(3)$ & 0.373541 & 0.022513 & 16.59226 & 0.0000 \\
$\beta(1)$ & -0.107688 & 0.036035 & -2.988437 & 0.0028 \\
$\beta(2)$ & 0.148013 & 0.335509 & 0.441160 & 0.0591 \\
\hline & & & & \\
T-DIST. DOF & 2.135290 & 0.067948 & 31.42523 & 0.0000 \\
\hline & & & & \\
\hline
\end{tabular}

Source: Computed using E-Views 11 Software Package (2019)

From table 4.2, the variance equation showed the presence of GARCH effect since all the GARCH parameters $\alpha(1), \alpha(2), \alpha(3)$ and $\beta(1)$ are significant and in the mean equation, the GARCH parameter is also significant as depicted by the probability value of 0.0000 which is lower than 0.01 ( 1 percent level of significance). This shows that volatility exists in exchange rate from 1990 to 2019.

From the variance equations $\alpha(1), \alpha(2), \alpha(3), \beta(1)$ and $\beta(2)$ above, exchange rate volatility was extracted.

\subsection{Unit root test}

Having established the exchange rate volatility, the next step is to compute the stationarity properties of the variables under investigation as follows: 
African Journal of Business and Economic Development | ISSN: 2782-7658

Vol. 1, Issue 5, Series 2 (May, 2021) | www.ijaar.org

Journal DOI: www.doi.org/10.46654/AJBED

Article DOI: www.doi.org/10.46654/AJBED.1533

Table 4.4: UNIT ROOT TEST (Augmented Dickey Fuller Test)

\begin{tabular}{|c|c|c|c|c|c|c|c|c|}
\hline Variable & Levels & \multicolumn{2}{|c|}{ Critical Values } & $\begin{array}{l}\text { First } \\
\text { differences }\end{array}$ & \multicolumn{2}{|c|}{ Critical Values } & Order of & \\
\hline \multirow{3}{*}{ INF } & \multirow{3}{*}{-2.847412} & $1 \%$ & -4.440739 & \multirow{3}{*}{-5.343534} & $1 \%$ & -4.394309 & \multirow{3}{*}{$\mathrm{I}(1)$} & \multirow{3}{*}{$\begin{array}{l}\text { Stationary } \\
\text { at } \quad 1^{\text {st }} \\
\text { difference }\end{array}$} \\
\hline & & $5 \%$ & -3.632896 & & $5 \%$ & -3.612199 & & \\
\hline & & $10 \%$ & -3.254671 & & $10 \%$ & -3.243079 & & \\
\hline \multirow{3}{*}{ EXRV } & \multirow{3}{*}{-3.473491} & $1 \%$ & -3.679322 & \multirow{3}{*}{-4.612287} & $1 \%$ & -4.416345 & \multirow{3}{*}{$\mathrm{I}(1)$} & \multirow{3}{*}{$\begin{array}{l}\text { Stationary } \\
\text { at } \quad 1^{\text {st }} \\
\text { difference }\end{array}$} \\
\hline & & $5 \%$ & -2.967767 & & $5 \%$ & -3.622033 & & \\
\hline & & $10 \%$ & -2.622989 & & $10 \%$ & -3.248592 & & \\
\hline \multirow{3}{*}{ MS } & \multirow{3}{*}{8.433056} & $1 \%$ & -4.416345 & \multirow{3}{*}{-4.992494} & $1 \%$ & -4.440739 & \multirow{3}{*}{$\mathrm{I}(1)$} & \multirow{3}{*}{$\begin{array}{l}\text { Stationary } \\
\text { at } \quad 1^{\text {st }} \\
\text { difference }\end{array}$} \\
\hline & & $5 \%$ & -3.622033 & & $5 \%$ & -3.632896 & & \\
\hline & & $10 \%$ & -3.248592 & & $10 \%$ & -3.254671 & & \\
\hline \multirow{3}{*}{ EGr } & \multirow{3}{*}{-3.131129} & $1 \%$ & -4.309824 & \multirow{3}{*}{-7.460081} & $1 \%$ & -4.323979 & \multirow{3}{*}{$\mathrm{I}(1)$} & \multirow{3}{*}{$\begin{array}{l}\text { Stationary } \\
\text { at } \quad 1^{\text {st }} \\
\text { difference }\end{array}$} \\
\hline & & $5 \%$ & -3.574244 & & $5 \%$ & -3.580623 & & \\
\hline & & $10 \%$ & -3.221728 & & $10 \%$ & -3.225334 & & \\
\hline \multirow{3}{*}{ UMP } & \multirow{3}{*}{-3.177009} & $1 \%$ & -4.356068 & \multirow{3}{*}{-4.891551} & $1 \%$ & -4.323979 & \multirow{3}{*}{$\mathrm{I}(1)$} & \multirow{3}{*}{$\begin{array}{l}\text { Stationary } \\
\text { at } \quad 1^{\text {st }} \\
\text { difference }\end{array}$} \\
\hline & & $5 \%$ & -3.595026 & & $5 \%$ & -3.580623 & & \\
\hline & & $10 \%$ & -3.233456 & & $10 \%$ & -3.225334 & & \\
\hline \multirow{3}{*}{ Bot } & \multirow{3}{*}{-2.567528} & $1 \%$ & -4.309824 & \multirow{3}{*}{-5.9536} & $1 \%$ & -4.323979 & \multirow{3}{*}{$\mathrm{I}(1)$} & \multirow{3}{*}{$\begin{array}{l}\text { Stationary } \\
\text { at } 1^{\text {st }} \\
\text { Difference }\end{array}$} \\
\hline & & $5 \%$ & -3.574244 & & $5 \%$ & -3.580623 & & \\
\hline & & $10 \%$ & -3.221728 & & $10 \%$ & -3.225334 & & \\
\hline
\end{tabular}

Source: Computed using E-Views 11 Software Package (2021)

From the above summary table of the Unit Root test using Augmented Dickey Fuller Test, it is evident that all variables are not stationary at level at $1 \%, 5 \%$ and $10 \%$ level of significance. However, when the variables were examined at first difference, they were stationary at first difference. This satisfies the requirements for using Vector Error Correction Mechanism (VECM) as the method of data analysis. Having successfully tested for stationarity at first difference, cointegration test was conducted to examine the long run relationship among the variables under study: 
African Journal of Business and Economic Development | ISSN: 2782-7658

Vol. 1, Issue 5, Series 2 (May, 2021) | www.ijaar.org

Journal DOI: www.doi.org/10.46654/AJBED

Article DOI: www.doi.org/10.46654/AJBED.1533

\section{Table 4.5 Cointegration Analysis}

Series: EXRV EGr INF UMP MSBoT

Lags interval (in first differences): 1 to 1

Unrestricted Cointegration Rank Test (Trace)

\begin{tabular}{ccccc}
\hline $\begin{array}{c}\text { Hypothesized } \\
\text { No. of CE(s) }\end{array}$ & Eigenvalue & $\begin{array}{c}\text { Trace } \\
\text { Statistic }\end{array}$ & $\begin{array}{c}0.05 \\
\text { Critical Value }\end{array}$ & ${\text { Prob. }{ }^{* *}}$ \\
\hline & & & & \\
None * & 0.977525 & 316.4731 & 139.2753 & 0.0000 \\
At most 1 * $_{\text {At most 2 * }}$ & 0.927032 & 210.2029 & 107.3466 & 0.0000 \\
At most 3 & 0.883168 & 136.9065 & 79.34145 & 0.0000 \\
At most 4 & 0.682812 & 76.78986 & 55.24578 & 0.0002 \\
At most 5 * & 0.542555 & 44.63857 & 35.01090 & 0.0035 \\
& 0.380830 & 22.73982 & 18.39771 & 0.0116 \\
\hline
\end{tabular}

Trace test indicates 5 cointegrating eqn(s) at the 0.05 level

${ }^{*}$ denotes rejection of the hypothesis at the 0.05 level

**MacKinnon-Haug-Michelis (1999) p-values

\section{Source: Author's computation using E-Views Software, Version 11 (2019)}

From the table 4.2 the Trace statistic is greater than the critical value for all the equations, hence, the null hypothesis of non-cointegration is rejected. This shows that there is long run relationship among the variables of study. 
African Journal of Business and Economic Development | ISSN: 2782-7658

Vol. 1, Issue 5, Series 2 (May, 2021) |www.ijaar.org

Journal DOI: www.doi.org/10.46654/AJBED

Article DOI: www.doi.org/10.46654/AJBED.1533

\subsection{VECM Short-run Result}

Table 4.5 VECM Short-run result

Vector Error Correction Estimates

Date: 07/10/20 Time: 20:05

Sample (adjusted): 19862019

Included observations: 34 after adjustments

Standard errors in ( )\& t-statistics in [ ]

\begin{tabular}{|c|c|c|c|c|c|c|}
\hline Error Correction: & $\mathrm{D}(\mathrm{EGr})$ & $\mathrm{D}(\mathrm{INF})$ & $\mathrm{D}(\mathrm{MS})$ & $\mathrm{D}(\mathrm{UMP})$ & $\mathrm{D}(\mathrm{BoT})$ & $\mathrm{D}(\mathrm{EXRV})$ \\
\hline CointEq1 & $\begin{array}{c}-0.000214 \\
(0.00091) \\
{[-5.00979]}\end{array}$ & $\begin{array}{r}-0.006560 \\
(0.00215) \\
{[-3.04475]}\end{array}$ & $\begin{array}{r}-7.14 \mathrm{E}-06 \\
(2.1 \mathrm{E}-06) \\
{[-3.38979]}\end{array}$ & $\begin{array}{r}-0.020418 \\
(0.03091) \\
{[-0.66056]}\end{array}$ & $\begin{array}{r}4.58 E-05 \\
(0.00071) \\
{[0.06486]}\end{array}$ & $\begin{array}{r}-0.006560 \\
(0.00215) \\
{[-3.04475]}\end{array}$ \\
\hline $\mathrm{D}(\mathrm{EGr}(-1))$ & $\begin{array}{l}0.019506 \\
(0.06867) \\
{[3.11565]}\end{array}$ & $\begin{array}{r}-0.011663 \\
(0.01659) \\
{[-0.70304]}\end{array}$ & $\begin{array}{r}1.82 E-05 \\
(1.6 E-05) \\
{[1.12459]}\end{array}$ & $\begin{array}{r}-0.083922 \\
(0.23799) \\
{[-0.35262]}\end{array}$ & $\begin{array}{r}0.003318 \\
(0.00544) \\
{[0.60985]}\end{array}$ & $\begin{array}{r}-0.011663 \\
(0.01659) \\
{[-0.70304]}\end{array}$ \\
\hline $\mathrm{D}(\mathrm{INF}(-1))$ & $\begin{array}{r}0.378225 \\
(0.17668) \\
{[3.22558]}\end{array}$ & $\begin{array}{r}0.031183 \\
(0.16490) \\
{[0.18910]}\end{array}$ & $\begin{array}{r}0.000188 \\
(0.00016) \\
{[1.16887]}\end{array}$ & $\begin{array}{r}-0.253693 \\
(2.36577) \\
{[-0.10723]}\end{array}$ & $\begin{array}{c}0.059921 \\
(0.05409) \\
{[1.10780]}\end{array}$ & $\begin{array}{r}0.031183 \\
(0.16490) \\
{[0.18910]}\end{array}$ \\
\hline $\mathrm{D}(\mathrm{MS}(-1))$ & $\begin{array}{l}5.475546 \\
(1.43570) \\
{[5.08138]}\end{array}$ & $\begin{array}{r}77.20749 \\
(141.203) \\
{[0.54678]}\end{array}$ & $\begin{array}{r}0.185783 \\
(0.13808) \\
{[1.34552]}\end{array}$ & $\begin{array}{r}1338.143 \\
(2025.76) \\
{[0.66056]}\end{array}$ & $\begin{array}{r}-1.257671 \\
(46.3159) \\
{[-0.02715]}\end{array}$ & $\begin{array}{r}77.20749 \\
(141.203) \\
{[0.54678]}\end{array}$ \\
\hline $\mathrm{D}(\mathrm{UMP}(-1))$ & $\begin{array}{l}0.128499 \\
(0.02770) \\
{[6.00627]}\end{array}$ & $\begin{array}{r}0.017380 \\
(0.01256) \\
{[1.38381]}\end{array}$ & $\begin{array}{r}-6.82 E-06 \\
(1.2 E-05) \\
{[-0.55536]}\end{array}$ & $\begin{array}{r}0.400043 \\
(0.18018) \\
{[2.22024]}\end{array}$ & $\begin{array}{r}0.000677 \\
(0.00412) \\
{[0.16423]}\end{array}$ & $\begin{array}{r}0.017380 \\
(0.01256) \\
{[1.38381]}\end{array}$ \\
\hline $\mathrm{D}(\mathrm{BoT}(-1))$ & $\begin{array}{r}4.747052 \\
(1.67778) \\
{[3.91481]}\end{array}$ & $\begin{array}{r}-1.252821 \\
(0.46007) \\
{[-2.72314]}\end{array}$ & $\begin{array}{r}-0.000202 \\
(0.00045) \\
{[-0.44932]}\end{array}$ & $\begin{array}{r}-19.51381 \\
(6.60027) \\
{[-2.95652]}\end{array}$ & $\begin{array}{r}-0.617344 \\
(0.15091) \\
{[-4.09093]}\end{array}$ & $\begin{array}{r}-1.252821 \\
(0.46007) \\
{[-2.72314]}\end{array}$ \\
\hline $\mathrm{D}(\mathrm{EXRV}(-1))$ & $\begin{array}{c}-0.378225 \\
(0.17668) \\
{[-3.22558]}\end{array}$ & $\begin{array}{r}0.431183 \\
(0.16490) \\
{[3.18910]}\end{array}$ & $\begin{array}{c}-0.000288 \\
(0.00016) \\
{[-2.86887]}\end{array}$ & $\begin{array}{l}0.253693 \\
(0.16577) \\
{[3.10723]}\end{array}$ & $\begin{array}{r}0.059921 \\
(0.02409) \\
{[3.10780]}\end{array}$ & $\begin{array}{r}0.031183 \\
(0.16490) \\
{[0.18910]}\end{array}$ \\
\hline $\mathrm{C}$ & $\begin{array}{r}-0.145185 \\
(0.15589) \\
{[-0.93134]}\end{array}$ & $\begin{array}{r}0.041895 \\
(0.01533) \\
{[2.73256]}\end{array}$ & $\begin{array}{r}-3.75 E-08 \\
(1.5 E-05) \\
{[-0.00250]}\end{array}$ & $\begin{array}{r}0.203728 \\
(0.21996) \\
{[0.92622]}\end{array}$ & $\begin{array}{r}0.011877 \\
(0.00503) \\
{[2.36174]}\end{array}$ & $\begin{array}{r}0.041895 \\
(0.01533) \\
{[2.73256]}\end{array}$ \\
\hline $\begin{array}{l}\text { R-squared } \\
\text { Adj. R-squared } \\
\text { F-statistic }\end{array}$ & $\begin{array}{l}0.940330 \\
0.893577 \\
9.301182\end{array}$ & $\begin{array}{l}0.953846 \\
0.849732 \\
9.438147\end{array}$ & $\begin{array}{l}0.981355 \\
0.881079 \\
9.805811\end{array}$ & $\begin{array}{l}0.905956 \\
0.895159 \\
9.858857\end{array}$ & $\begin{array}{l}0.938200 \\
0.845856 \\
9.662385\end{array}$ & $\begin{array}{l}0.953846 \\
0.849732 \\
9.438147\end{array}$ \\
\hline
\end{tabular}

\section{Source: Author's computation using E-Views Software, Version 11 (2019)}

From the VECM results, the short-run interpretation of the results is given with exchange rate volatility as the independent variable as follows: 
For the EGr equation, a unit increase in exchange rate volatility in the short-run will lead to 0.378225 decrease in EGr (Economic Growth). The result is statistically significant at 5 percent level of significance as indicated by t-statistic value of 3.22558 which is greater than the theoretical t-value of 2.68 at 5 percent level of significance.

For the INF equation, a unit increase in exchange rate volatility in the short-run will lead to 0.431183 increase in INF (Inflation Rate). The result is statistically significant at 5 percent level of significance as indicated by $t$ statistic value of 3.18910 which is greater than the theoretical $t$ value of 2.68 at 5 percent level of significance.

For the MS equation, a unit increase in exchange rate volatility in the short-run will lead to 0.000288 decrease in MS (Money supply). The result is statistically significant at 5 percent level of significance as indicated by the $t$ statistic value of 2.86887 which is greater than the theoretical $t$ value of 2.68 at 5 percent level of significance.

For the UMP equation, a unit increase in exchange rate volatility in the short-run will lead to 0.253693 increase in UMP (Unemployment Rate). The result is statistically significant at 5 percent level of significance as indicated by t statistic value of 3.10723 which is greater than the theoretical t value of 2.68 at 5 percent level of significance.

Having established both the long and short run impacts of exchange rate on macroeconomic performance, it is pertinent that the forecasting power of the model be determined through the decomposition of the variance and the impulse response function. This is analysed in Tables 4.9 and 4.10 below:

\subsubsection{Impulse Response Function}

Impulse response function is determined through an in-depth impulse response analysis that helps to quantify the reaction of every single variable in the model on an exogenous shock to the model. The reaction is usually measured for every variable at a given time a shock occurs. The reaction of another economic variable to the impulse is referred to as the response. It is derived from the estimated VECM. Table 4.10 explains the response of the variables under investigation to impulse from exchange rate volatility: 

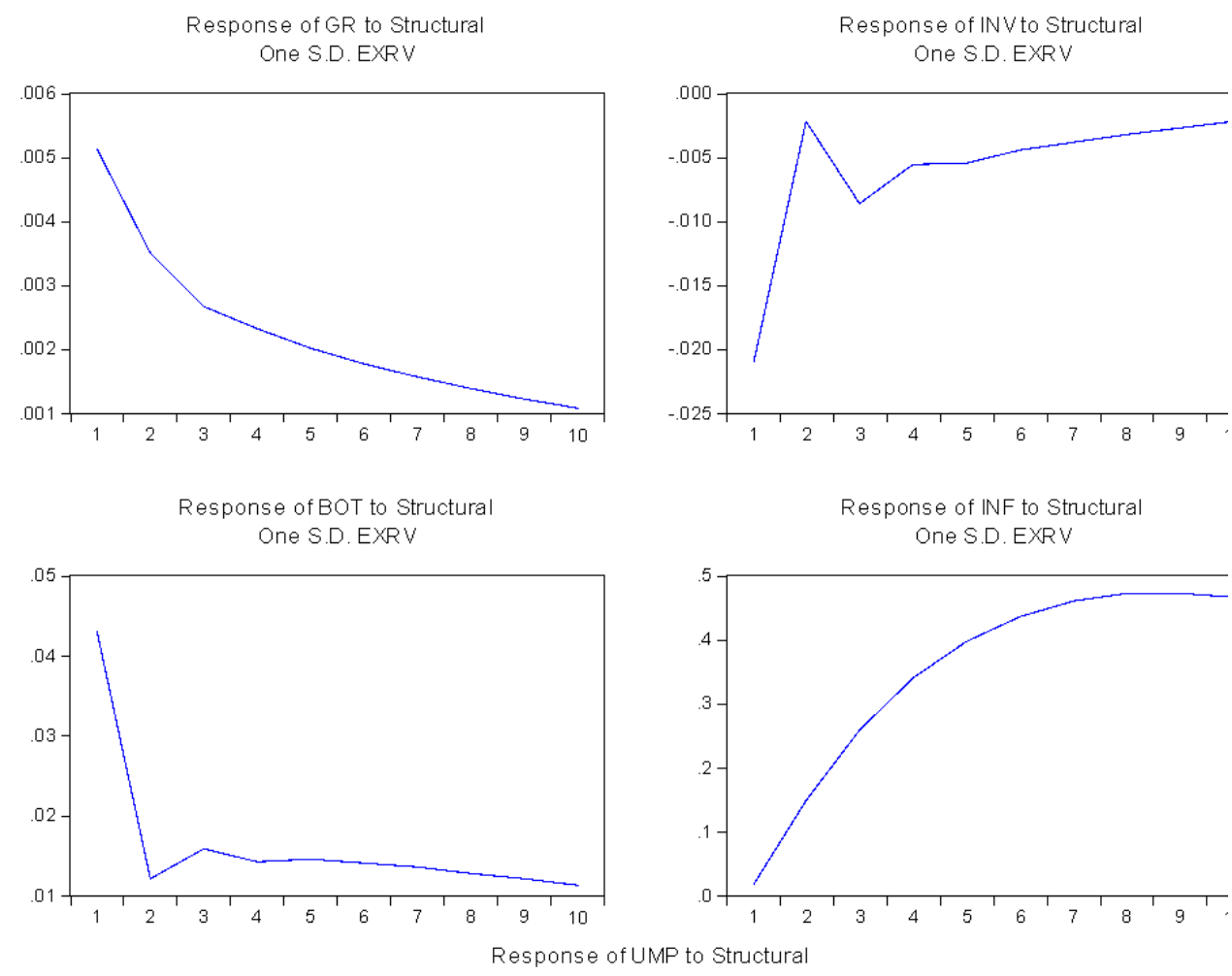

One S.D. EXRV

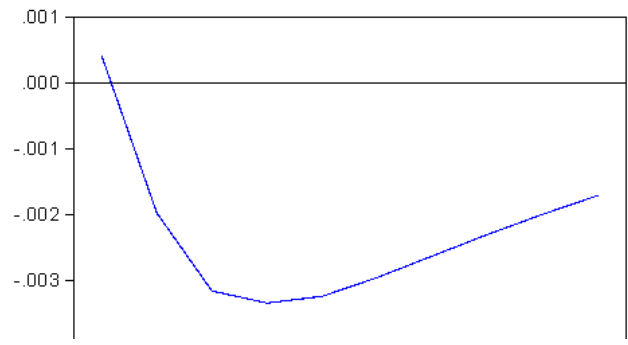

Figure 4.4 Impulse Response Function (IRF)

\section{Source: Author's Computation using E-Views 11 Software Package (2019)}

Figure 4.4 graphically depicts responses of EGr, MS, BoT, INF and UMP to a shock in exchange rate volatility over a period of ten (10) years. As seen in the graph, there is a positive, but declining response from EGr to a shock in EXRV. There is an indication from the declining rate that if shock continues into the future, response from EGr may eventually be zero and even negative. The positive response of EGrto EXRV is not a good signal for the Nigerian economy as it means that as the value of naira to dollar depreciates; that is, more units of naira will be given up to get a unit of dollar, it will reduce economic growth from period 1 to period 10 as indicated from the impulse response graph and table.MS is seen to have a decreasing negative response to shock in EXRV. The response from first period up to third period were unstable but stable afterward and it is leaning towards the positive region as indicated from its position in the last $\left(10^{\text {th }}\right)$ period.

Similarly, shock in EXRV causes a decreasing positive response from BoT. It is observed that there is a sharp decrease between the response in first period and second period, a fluctuating one from the second to the fifth after which the response became stable by 
declining at a seemingly constant rate. If this continues into the future, response of BoT may eventually be zero and probably negative. There is an indication that INF has direct relationship with shocks in EXRV. Its response over time is positive and an increasing one until the ninth period where the response reaches its peak and starts declining. This suggests that INF response to shock in EXRV and at later period will be minimal compared to earlier period. UMP response to volatility in exchange rate is at its highest in the first period after which it assumes a continuous decrease to the seventh period where the downturn occurs. There is an indication that if the trend continues, UMP may eventually be zero and assumes positive response to persistence shock in exchange rate.

The impulse response analysis and the variance decomposition carried clearly depicts that any sudden changes in any of the variables have the tendency of impacting on other variables.

\section{Conclusion and Policy Implications}

The empirical results show that exchange rate volatility has a significant impact on economic performance. This result indicated that exchange rate volatility discourages economic growth, which supports many previous studies (e.g. Enu, Osei-Gyimah and Opoku 2013). This finding also suggests that the volatility of exchange rate has played an important role in the fluctuations of macroeconomic performance in Nigeria over the years. In addition, the results also suggest that volatility of the exchange rate adversely affects money supply in Nigeria. This finding supports the claim that a floating exchange rate may work as an economic stabilizer to mitigate external disequilibria. Moreover, the robustness checks of Variance Decompositions and Impulse Response Functions analysis supports the findings from VECM model.

Based on the findings above, many policy implications can be drawn regarding the relationship between exchange rate volatility and macroeconomic indicators in Nigeria.

a. First and foremost, reducing exchange rate volatility is quite crucial to mitigate its negative impact on money supply and output growth. Serious attention should be paid to factors that stimulate exchange rate fluctuations like high inflation and budget deficit. Thus, policymakers should consider adopting inflation targeting as a strategy in addition to the autonomy of the monetary policy.

b. Furthermore, relevant authorities should try to avoid systematic currency devaluations in order to maintain exchange rate volatility at a rate that allows adjustment of the balance of payments.

c. Considering the current shortage of foreign exchange in Nigeria, the economy needs an effective exchange rate policy in order to overcome the unfavorable impact of declining foreign reserves. Therefore, an encouraging exchange rate should be offered for foreign transactions and transfers to attract flows of foreign capital such as FDI and migrants' remittances. In addition, diversification of the economy should be considered as a top priority within the development agenda. In this respect, managing a competitive exchange rate would be a crucial tool to enhance productivity of the domestic sectors. 
African Journal of Business and Economic Development | ISSN: 2782-7658

Vol. 1, Issue 5, Series 2 (May, 2021) | www.ijaar.org

Journal DOI: www.doi.org/10.46654/AJBED

Article DOI: $\underline{\text { ww.doi.org/10.46654/AJBED.1533 }}$

d. Moreover, trade cooperation with neighbouring countries in the region would be helpful in increasing foreign earnings, particularly in the short run that would to boost the growth of the nation's economy. 


\section{References}

Adeniran, A., Yusuf, A. and Adeyemi, O. (2014). Exchange Rate and Economic Growth. Journal of Economic and Social Research, (3), 1- 4

Akintola, M and Lawal, O. (2012) .Exchange Rate Variability and Investment in Nigeria, Revisiting the Case for Flexible Exchange Rates: Journal of economics Volume 5.

Aliyu, O. (2011) 'Does Devaluation Hurt Private Investment?', PPR Working Paper Series, No. 418, World Bank.

Attah-Obeng, A., Enu, A., Osei-Gyimah, O. and Opoku, D. (2014). Exchange Rate and Economic Growth. Journal of Economic and Social Research, (3), 1- 4.

Azeez, M., Kolapo, O. and Ajayi, A (2012). "The Impact of Exchange Rate Uncertainty on the Level of Investment", The Economic Journal, 109:55-67.

Barguellil, A., Ben-Salha, O. and Zmami, M. (2018). Exchange Rate Volatility and Economic Growth. Journal of Economic Integration (JEI). Volume 33 No 2.

Benita, A. and Lauterbach, M. (2007). "The effect of nominal exchange rate volatility on real macroeconomic performance in the CEE countries,"Economic Systems, Elsevier, vol. 35(2), pages 261-277, June.

Berument, P. Ali, A. and Clement, A. (2012). Exchange Rate Volatility and Economic Growth in Turkey. International Journal of Economics, Commerce and Management United Kingdom Vol. V, Issue 7.

Central bank of Nigeria (CBN) (2019). Statistical Bulletin @ www.CBN.ng/Statistics_Statistical_Bulletin.

Dada, M. and Oyeranti, O. (2012). "The Impact of Exchange Rate Uncertainty on the Level of Investment", The Economic Journal, 109:55-67.

Danmola, O. (2013) 'Does Devaluation Hurt Private Investment?', PPR Working Paper Series, No. 418, World Bank.

Dahiru A. B. and Asemota, J. O. (2013). Exchange-Rates Volatility in Nigeria: Application of GARCH Models with Exogenous Break. CBN Journal of Applied Statistics Vol.4 No.1 (June, 2013) 89.

Ehinomen, M. and Oladipo, O. (2014). "The Impact of Exchange Rate Uncertainty on the Level of Investment”, The Economic Journal, 109:55-67.

Fisher, I. (1938). A Quantity Theory of Money. Longman Publisher, London, United Kingdom.

Holland, A. and Allan, P. and Mork, P. (2011). Exchange rate Volatility and Trade. National Economic Review. Pp75-90.

Holland, A., Vieira, M. and Bottecchia, P. (2011). Exchange Rate Volatility and Economic Growth in a Panel of Countries. Journal of Economic and Social Research, (5), 11-3 4 
African Journal of Business and Economic Development | ISSN: 2782-7658

Journal DOI: www.doi.org/10.46654/AJBED

Vol. 1, Issue 5, Series 2 (May, 2021) | www.ijaar.org

Article DOI: www.doi.org/10.46654/AJBED.1533

Gadanecz, A. and Mehrotra, L. (2013). Exchange Rate and Economic Growth. Journal of Economic and Social Research, (3), 1- 4

Ganesh, A, I., Moses, L. and Musyoki, M. C. (2012). Exchange Rate Volatility and Economic Growth in Kenya. International Journal of Economics, Commerce and Management United Kingdom Vol. V, Issue 6,

Ismaila, O.B. (2016) "Exchange Rate Uncertainty and Foreign Direct Investment in Nigeria", Trade Policy Research and Training Programme (TPRTP), University of Ibadan, Nigeria.

Iyeli, i. and Utting, c. (2017). Exchange Rate Volatility and Economic Growth in Nigeria. International Journal of Economics, Commerce and Management United Kingdom Vol. V, Issue 7 ,

Kashif, A. Slade, M.E., Blaze, K. (2010). Trends in natural-resource commodity prices: an analysis of the time domain. Journal of Environmental Economics and Management, vol 9, p.122-137.

Matthews, T. (2010). An essay on the principle of Volatility, St. Paul's Church Yard,London.

Mori, A., Asid, A., Lily, K. and Loganathan, O. (2012). Exchange Rate and Economic Growth. Journal of Economic and Social Research, (3), 1- 4

Ogunjuyigbe, O. and Laisu, M. (2010). 'Does Devaluation Hurt Private Investment?', PPR Working Paper Series, No. 418, World Bank.

Pindyck, R., (2002). "Volatility, Uncertainty and Returns," Policy Research Working Paper Series 304, The World Bank. Handle.

Polodoo, L, Seetenah, M and Padachi, Y. (2011). Exchange Rate and Economic Growth. Journal of Economic and Social Research, (3), 1- 4

Phillip, I.H. and Moon, A, (1999). Unit-root test and dynamic heterogenous panels, Journal of Econometrics 68, 70-115.

Rasaq, M. (2012). "The Impact of Exchange Rate Uncertainty on the Level of Investment", The Economic Journal, 109:55-67.

Shiller, I. and Radikoko, I. (2014). This study tests the validity of the weak-form EMH on the Canadian TSX equity market using seven Companies. Journal of Applied Economics, Volume 4 pp 44-90.

Tarawalie, A. Robinson, P., Allan, K. (2012). Exchange rate Alignment and Trade. National Economic Review. Pp55-60.

Tsay, K. (2002). Statistical inference in instrumental variables regression with I(1) processes, Review of Economic Studies 57, 99-125.

Ubah, I. (2014). Impact of Exchange Rate Volatility and Economic Growth. Journal of Economic and Social Research, (3), 1- 4

Umaru, H., Niyi, A. and Osagie, N. (2019). The Effects of Exchange Rate Volatility on Economic Growth of West African English-Speaking Countries. International Journal of Academic 
African Journal of Business and Economic Development | ISSN: 2782-7658

Vol. 1, Issue 5, Series 2 (May, 2021) | www.ijaar.org

Journal DOI: www.doi.org/10.46654/AJBED

Article DOI: www.doi.org/10.46654/AJBED.1533

Research in Accounting, Finance and Management Sciences, Vol. 8, No.4, October 2018, pp. $131-143$

Yaqub, M. (2010). "The Impact of Exchange Rate Uncertainty on the Level of Investment", The Economic Journal, 109:55-67. 